\title{
One long umbilical cord, four nuchal cord loops and a true knot
}

\author{
Reine Zbeidy, Fouad Ghazi Souki
}

Department of Anesthesiology, University of Miami, Miller School of Medicine, Miami, Florida, USA

Correspondence to Dr Reine Zbeidy, rzbeidy@med.miami.edu

Accepted 28 November 2017

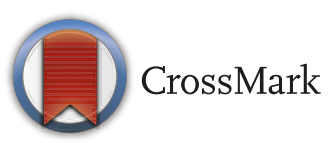

To cite: Zbeidy R, Souki FG. BMJ Case Rep Published Online First: [please include Day Month Year]. doi:10.1136/bcr-2017223241

\section{DESCRIPTION}

A 43-year-old woman G4 P2101 at 36 weeks of gestation presented to the labour floor with non-reactive fetal heart tracing and decreased fetal movement. She had a second-trimester ultrasound showing intrauterine growth retardation (IUGR). Patient had a history of hypothyroidism, two fetal demises at term and a planned preterm delivery at 34 weeks of gestation via caesarean section. Workup was negative for thrombophilia (lupus anticoagulant, anticardiolipin, anti-b2-glycoprotein, factor $\mathrm{V}$ Leiden, protein $\mathrm{S}$, protein C, G20210 mutation, antithrombin III, antinuclear antibodies) and infectious diseases. Placental pathology following her second fetal demise revealed chorioamnionitis and necrotising funisitis with negative amniotic fluid cultures. There was no information regarding umbilical cord (UC) length or entanglements in previous pregnancies.

Given her history and the current non-reactive fetal heart tracing, the patient was taken for emergency caesarean delivery. A female infant was born with four loops of nuchal cord and a true knot (figure 1). Apgar scores were 7 at $1 \mathrm{~min}$ and 9 at 5 and $10 \mathrm{~min}$. Baby weighed $1550 \mathrm{~g}$. Examination of the placenta showed an excessively long umbilical cord (ELUC) measuring $93 \mathrm{~cm}$. A normal UC is $55-61 \mathrm{~cm}$ long.

Long umbilical cords are present in $4 \%$ of placentae and pose a higher risk for cord entanglement (ie, true knots or cord loops around the neck or body parts), circulatory stasis and vascular thrombosis. ${ }^{1}$ This can cause perinatal complications, IUGR, neurological damage and fetal death. Mothers with a history of an ELUC are at increased risk of a long cord in subsequent pregnancies. ${ }^{1}$

The most common cord entanglement is nuchal cord with an incidence of $15 \%-34 \%$; single loop 24\%-28\% and multiple loops $0.5 \%-3.3 \%{ }^{2}$ During the third trimester, two-dimensional sonography can detect a nuchal cord with a sensitivity of $85 \%$ and specificity of $89 \% .^{3}$ A single nuchal cord is not associated

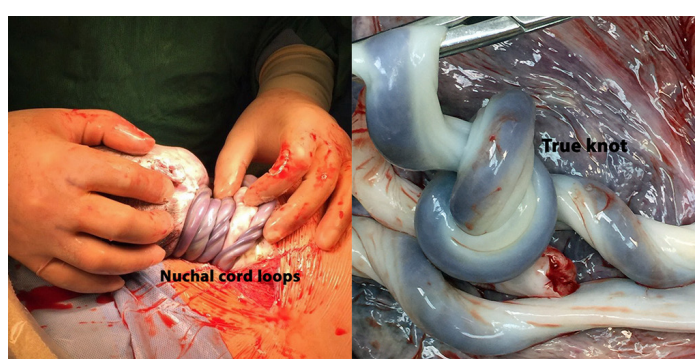

Figure 1 Long umbilical cord with four nuchal cord loops (left) and true knot (right). with any adverse perinatal outcome. However, Kong et $a l^{3}$ found a higher incidence of fetal distress and emergency caesarean deliveries with three loops of nuchal cords or more.

True knots are reported in $0.4 \%-1.2 \%$ of deliveries. ${ }^{2}$ A long UC, gestational diabetes, polyhydramnios and multiparity increase the incidence of a true knot. Although not all true knots lead to perinatal problems, they have been associated with IUGR, fetal distress, fetal hypoxia, perinatal mortality, long-term neurological damage and caesarean delivery. ${ }^{134}$ In one study, the OR for emergency caesarean deliveries due to non-reassuring fetal heart rate was 2.7 for true knot and 2.9 for multiple UC loops, respectively. ${ }^{4}$

Patient's history of term pregnancies with fetal demise, and her negative workup, left us wondering if an ELUC associated with cord entanglements had occurred in previous pregnancies. Currently, there are no guidelines on counselling and management of patients with a true knot or nuchal cord diagnosed by antenatal sonography. Reporting these findings can lead to parental anxiety and potential medicolegal implications without improving outcomes. This case illustrates the association between an extremely long UC, cord entanglement, intrauterine growth restriction, possibility of fetal demise and need for emergency delivery.

\section{Learning points}

- Excessively long umbilical cord can lead to cord entanglement.

- Cord entanglement can lead to perinatal complications.

- Antenatal diagnosis of multiple cord entanglements should alert the medical team to the possibility of emergency delivery.

Contributors RZ was involved in care of the patient, writing and editing the manuscript. FGS was invovled in writing and editing manuscript and image.

Competing interests None declared.

Patient consent Obtained.

Provenance and peer review Not commissioned; externally peer reviewed.

(c) BMJ Publishing Group Ltd (unless otherwise stated in the text of the article) 2017. All rights reserved. No commercial use is permitted unless otherwise expressly granted.

\section{REFERENCES}

1 Baergen RN, Malicki D, Behling C, et al. Morbidity, mortality, and placental pathology in excessively long umbilical cords: retrospective study. Pediatr Dev Pathol 2001;4:144-53.

2 Guzikowski W, Kowalczyk D, Więcek J. Diagnosis of true umbilical cord knot. Arch Med Sci 2014;10:91-5. 
3 Kong CW, Chan LW, To WW. Neonatal outcome and mode of delivery in the presence of nuchal cord loops: implications on patient counselling and the mode of delivery. Arch Gynecol Obstet 2015;292:283-9.
4 Weiner E, Fainstein N, Schreiber L, et al. The association between umbilical cord abnormalities and the development of non-reassuring fetal heart rate leading to emergent cesarean deliveries. J Perinatol 2015;35:919-23.

Copyright 2017 BMJ Publishing Group. All rights reserved. For permission to reuse any of this content visit http://group.bmj.com/group/rights-licensing/permissions.

BMJ Case Report Fellows may re-use this article for personal use and teaching without any further permission.

Become a Fellow of BMJ Case Reports today and you can:

- Submit as many cases as you like

- Enjoy fast sympathetic peer review and rapid publication of accepted articles

- Access all the published articles

Re-use any of the published material for personal use and teaching without further permission

For information on Institutional Fellowships contact consortiasales@bmjgroup.com

Visit casereports.bmj.com for more articles like this and to become a Fellow 